\title{
Evaluasi Faktor Keberhasilan Sistem Informasi Transportasi Online Berbasis Mobile Dalam Perspektif Kepuasan Pelanggan
}

\author{
Verry Riyanto ${ }^{1}$, Susy Rosyida ${ }^{2}$, Ridwansyah ${ }^{3}$ \\ ${ }^{1}$ Teknik Informatika \\ Sekolah Tinggi Manajemen Informatika dan Komputer Nusa Mandiri \\ e-mail: verry.vry@nusamandiri.ac.id \\ ${ }^{2}$ Teknik Informatika \\ Sekolah Tinggi Manajemen Informatika dan Komputer Nusa Mandiri \\ e-mail: susyrosyida@gmail.com \\ ${ }^{3}$ Teknik Informatika \\ Sekolah Tinggi Manajemen Informatika dan Komputer Nusa Mandiri \\ e-mail: rdwansyah@gmail.com
}

Cara Sitasi: Riyanto, V., Rosyida, S., \& Ridwansyah, R. (2019). Evaluasi Faktor Keberhasilan Sistem Informasi Transportasi Online Berbasis Mobile Dalam Perspektif Kepuasan Pelanggan. Paradigma - Jurnal Komputer dan Informatika, 21(2), 197-204. doi:10.31294/p.v21i2.6449

\begin{abstract}
One of the most important sectors in determining the success of the development process in developing countries is transportation. Existing transportation such as land, air and sea transportation. Of the three types of transportation, in Indonesia, the fastest development of island transportation. The rapid growth of transportation is evidenced by the increasing number of motorcycle transportation by $7.40 \%$ per year. This amount is supported by factors in the development and utilization of information technology that is increasingly growing in Indonesia. Behind that, it turns out there is support from the many companies developing technology to build transportation applications. As with online transportation that can provide land transportation facilities only by utilizing smartphone technology. The development of online transportation is one of the important factors in the use of transportation vehicles in Indonesia. Previous transportation has the facilities and infrastructure in the use of transportation is still minimal, namely the lack of providing services to the community so that people do not feel satisfied. Therefore, we conducted a study to evaluate the success factors of using land transportation from an online transportation application in the perspective of customer satisfaction using the AHP method that can overcome complex, unstructured problems such as expert thought, from the results obtained by the main factors that are very influential with the success of an application can be seen from the level of technological confidence of the application.
\end{abstract}

Keywords: Success Factors, Customer Satisfaction.

\section{PENDAHULUAN}

Di kota-kota besar Indonesia seperti Jakarta maupun kota sekitarnya, perkembangan roda perekonomian sangat berpengaruh dengan adanya akses transportasi yang ada. Karena transportasi yang efektif dan efisien (Ekawati \& Niken, 2014) yang memudahkan pengguna dalam kegiatan aktifitasnya merupakan salah satu faktor pendukung berkembangnya sebuah kota di berbagai bidang seperti di bidang hukum, sosial, ekonomi dan politik (Zaini, 2012). Saat ini banyaknya kendaraan transportasi umum sudah semakin banyak, namun semakin banyak sarana transportasi umum semakin banyak pula transportasi pribadi. Sarana dan prasarana transportasi umum (Minesa, Siregar, \& Manuwoto, 2014) kurang diminati karena salah satunya ketidaknyamanan bagi masyarakat sehingga cenderung masyarakat lebih memilih menggunakan sarana transportasi pribadi. Hal ini mengakibatkan kemacetan atau menumpuknya jumlah kendaraan pribadi, terlebih lagi banyak faktor-faktor yang mempengaruhi ketidakpuasan (Nadhiroh, 2019) terhadap transportasi umum sehingga transportasi online menjadi sebuah pilihan yang terbaik bagi para pengguna karena kepercayaan, kualitas sistem, kualitas konten, pelayanan online dan penggunaan aplikasi. 
Untuk mengatasi permasalahan tersebut, pemerintah DKI Jakarta merupakan sudah mulai memperhatikan transportasi umum serta penggunaan sarana dan prasarana transportasi umum dengan meningkatkan pelayanan (Rahma, Soeaidy, \& Hadi, 2013) yang terbaik kepada masyarakat. Selain itu, perkembangan ilmu pengetahuan dan teknologi juga sudah semakin berkembang (Ngafifi, 2014), banyak perusahaan-perusahaan yang menciptakan suatu inovasi terbaru dalam membangun sebuah sistem informasi manajeman dalam pembangunan di bidang transportasi yaitu berupa transportasi online.

Transportasi online merupakan sarana transportasi umum roda dua maupun transportasi umum roda empat yang memberikan layanan secara online dan memberikan pelayanan yang baik bagi masyarakat (Abdul, Nasution, \& Awin, 2017), yang menjadi berita utama di seluruh kota di Indonesia terutama DKI Jakarta dengan memberikan pelayanan dan harga yang baik dan cukup terjangkau. Transportasi online dibuat oleh perusahaan dengan membuat sebuah aplikasi untuk mempermudah masyarakat dalam perjalanannya dengan mengetahui informasi seorang pengemudi online yang mengambil pesanan dari aplikasi berupa sebuah foto dan kontak telepon. Harga yang tertera di aplikasi sangat transparan sehingga masyarakat atau pengemudi dapat melihat sebelum memesan atau mengambil pesanan.

Semakin banyak pengguna transportasi online maka membuat perusahaan lain untuk bisa berkembang juga di bidang transportasi yaitu dengan mengikuti membuat aplikasi transportasi online. Sehingga sekarang ini banyak perusahaan-perusahaan untuk bersaing dalam bidang transportasi online (Tresiya, Djunaidi, \& Subagyo, 2018). Masing-masing aplikasi yang dibuat oleh perusahaan-perusahaan tersebut pastinya mempunyai kelebihan dan kekurangannya.

Oleh karena itu, pada penelitian ini kami mengambil objek penelitian pada mitra perusahaan transportasi online yaitu Gojek dan Grab dengan menggunakan Analytical Hierarchy Process (AHP) untuk mengevaluasi faktor keberhasilan suatu sistem informasi transportasi online berbasis mobile dalam perspektif kepuasan pelanggan. Aplikasi Gojek dan Grab yang kami ambil sebagai objek penelitian dikarenakan lebih banyak digunakan oleh masyarakat saat ini sehingga kami ingin mengetahui faktor keberhasilan sistem informasi yang telah memberi pengaruh besar pada masyarkat. Sehingga nantinya dapat dikembangkan lagi oleh peneliti maupun perusahaan transportasi online lainnya atau pemerintah dapat membangun, mengakomodir perkembangan sistem informasi tersebut.

\section{METODOLOGI PENELITIAN}

Tahapan penelitian penentuan faktor keberhasilan sebuah sistem informasi transportasi online berbasis mobile dengan pendekatan Analytical Hierarchy Process (AHP), berikut tahapanya:

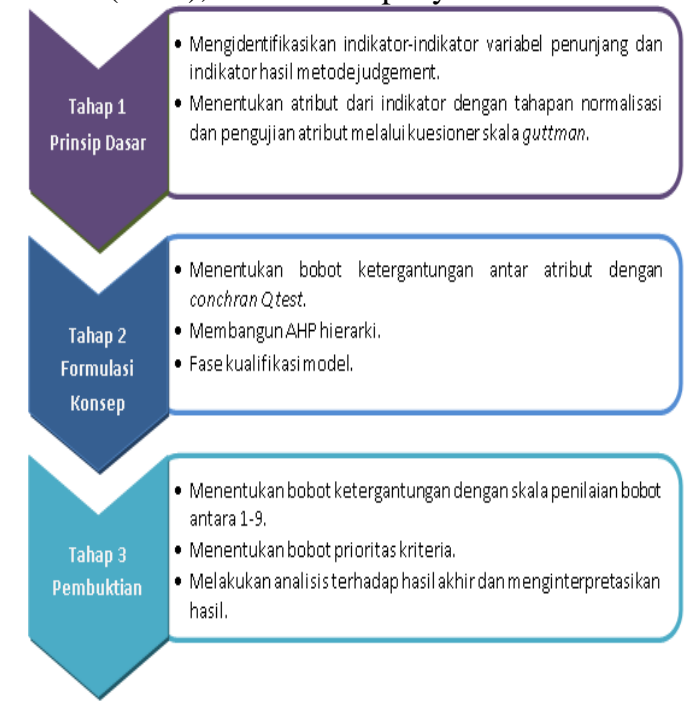

Sumber: (Riyanto, Rosyida, \& Ridwansyah, 2018)

Gambar 1. Tahapan Penelitian

\section{Tahap 1:}

1. Mengidentifikasikan indikator-indikator variabel penunjang yang diambil dari tiga buah referensi artikel ilmiah dan digabung dengan tiga indikator hasil metode judgement.

2. Menentukan atribut-atribut dari indikator tersebut dengan tahapan normalisasi atribut agar tidak terdapat atribut yang redudansi dan pengujian atribut melalui kuesioner skala guttman kepada responden dengan tehnik Purposive sampling.

\section{Tahap 2:}

Menentukan bobot ketergantungan antar atribut untuk mengetahui seberapa besar suatu atribut tergantung pada kriteria yang lain di dalam lingkup permasalahan tersebut dengan conchran Q test. Uji Cochran Q diperkenalkan oleh William Gemmell Cochran pada tahun 1909-1980. Uji Cohcran digunakan untuk menganalisis secara statistik tingkat keberhasilan dari suatu data tertentu. Hipotesis yang diuji adalah hipotesis terhadap beberapa variabel dikotomi yang memiliki arti sama. Cochran mengusulkan uji dimana sampel yang digunakan lebih dari 2 atau lebih sampel. Berikut ini adalah penjelasan uji Cochran Q:

$$
T=k \frac{(k-1) \sum_{j=1}^{k}\left(X_{. j}-\frac{N}{k}\right)^{2}}{\sum_{i=1}^{b} X_{i .}}\left(k-X_{i .}\right)
$$

\section{Tahap 3}

1. Menentukan bobot ketergantungan antar kriteria untuk mengetahui seberapa besar suatu kriteria tergantung pada kriteria yang lain didalam 
lingkup permasalahan tersebut dengan skala penilaian bobot antara 1 - 9 .

2. Menentukan bobot prioritas kriteria untuk masing-masing kriteria dengan mengalikan bobot kepentingan kriteria dengan bobot ketergantungan kriteria.

3. Melakukan analisis terhadap hasil akhir dan menginterpretasikan hasil dengan mengamati seberapa besar atau kecil ini adalah rasio.

\section{HASIL DAN PEMBAHASAN}

Metode penelitian yang digunakan dalam penentuan faktor keberhasilan sebuah sistem informasi transportasi online berbasis mobile dengan pendekatan Analytical Hierarchy Process (AHP), di mana dalam penentuan indikator variabel dan atribut digambarkan pada diagram gambar 2 .

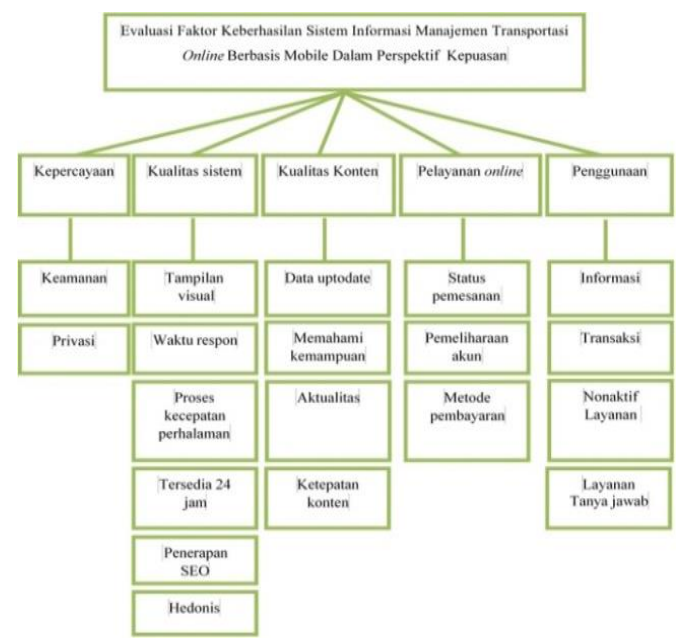

Sumber: (Riyanto et al., 2018)

Gambar 2. Diagram Hirarki dan Keputusan

Kami memilih responden di level strategis sebagai pelaku pengguna aplikasi yaitu penumpang aplikasi online yang berhubungan langsung dengan driver aplikasi transportasi online di mana para responden tersebut yang menentukan keputusan dalam menentukan faktor manakah yang berpengaruh dalam keberhasikan alat transportasi online yang mereka gunakan. Responden yang dipilih meliputi pelajar, mahasiswa dan karyawan yang bersinanggungan langsung dengan layanan aplikasi transportasi online tersebut. adapun Jumlah responden dalam penelitian ini berjumlah 586 responden yang diambil dari ketiga kriteria tersebut. Untuk detail responden ditunjukkan dalam tabel 1 di bawah ini:

Tabel 1 Responden Kuesioner

\begin{tabular}{clc}
\hline No & \multicolumn{1}{c}{ Responden } & Jumlah \\
\hline 1 & Pelajar & 50 \\
2 & Mahasiswa & 207 \\
3 & Karyawan & 329 \\
\hline & Jumlah & $\mathbf{5 8 6}$
\end{tabular}

Sumber: (Riyanto et al., 2018)
Berikut tahapan pengolahan data responden dalam menentukan faktor-faktor keberhasilan pada sistem informasi transportasi online melalui penerapan AHP:

1. Membentuk model keputusan dari kriteria dan subkriterianya dari variabel yang telah dianggap valid.

2. Membuat kuantifikasi model pada setiap kriteria dan subkriteria berdasarkan data kuesioner yang telah dikumpulkan dari kuesioner tahap dua, di mana responden diambil dari berbagai macam kriteria responden dengan secara langsung.

3. Menghitung nilai rasio konsistensi kriteria atau sub kriteria pada setiap data responden dengan nilai rasio konsistensi harus lebih kecil sama dengan $10 \%$ atau 0.1 , agar penilaian data responden dapat diterima atau valid karena dianggap konsisten.

4. Mengambil nilai prioritas di tiap-tiap kriteria suatu variabel untuk menentukan kriteria manakah yang mempunyai bobot nilai yang paling tinggi.

5. Menyimpulkan hasil akhir, faktor manakah yang paling berpengaruh terhadap keberhasilan pada suatu sistem informasi transportasi online, dilihat secara keseluruhan maupun sudut prespektif responden masing-masing

Pada gambar 3. Menjelaskan tentang menentukan atribut dari indikator dengan tahapan normalisasi.

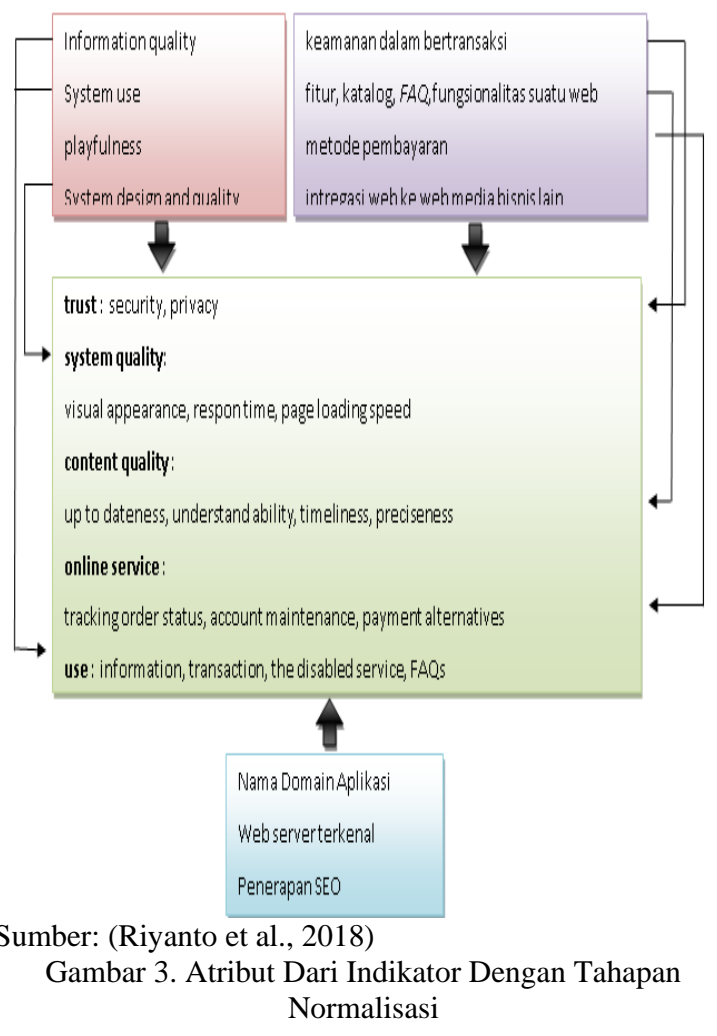

Dibawah ini merupakan pengujian kesepakatan atribut dengan Cochran Q Test 


\begin{tabular}{|c|c|c|}
\hline \multicolumn{3}{|c|}{ Frequencies } \\
\hline & \multicolumn{2}{|c|}{ Value } \\
\hline & o & 1 \\
\hline KEAMANAN & 6 & 21 \\
\hline PRIVASI & 7 & 20 \\
\hline WAKTU RESPON & 8 & 19 \\
\hline TAMPILAN VISUAL & 5 & 22 \\
\hline TERSEDIA 24JAM & 5 & 22 \\
\hline $\begin{array}{l}\text { PROSES KECEPATAN } \\
\text { HALAMAN }\end{array}$ & 8 & 19 \\
\hline $\begin{array}{l}\text { MEMAHAMI KEMAMPUAN } \\
\text { FLATFORM }\end{array}$ & 8 & 19 \\
\hline DATA UP TO DATE & 6 & 21 \\
\hline KETEPATAN KONTEN & 5 & 22 \\
\hline AKTUALITAS & 3 & 24 \\
\hline $\begin{array}{l}\text { PEMELIHARANAAN } \\
\text { AKUNN }\end{array}$ & 7 & 20 \\
\hline STATUS PESANAN & 2 & 25 \\
\hline INFORMASI & 1 & 26 \\
\hline $\begin{array}{l}\text { KEMUDAHAN } \\
\text { TRANSAKSI }\end{array}$ & 3 & 24 \\
\hline NONAKTIF PELAYANAN & 7 & 20 \\
\hline TRANSAKSI & o & 27 \\
\hline HEDONIS & 5 & 22 \\
\hline PENERAPAN SEO & 23 & 4 \\
\hline LAYANAN TANYA JAWAB & 8 & 19 \\
\hline $\begin{array}{l}\text { WEB SERVER } \\
\text { TERKENAL }\end{array}$ & 24 & 3 \\
\hline NAMA DOMAIN MENARIK & 24 & 3 \\
\hline $\begin{array}{l}\text { INTEGRASI WEBSITE } \\
\text { LAIN }\end{array}$ & 7 & 20 \\
\hline
\end{tabular}

Sumber: (Riyanto et al., 2018)

Gambar 4. Pengujian Atribut Dengan Cochran Q Test

Tabel 2. Test Statistics Pengujian

\begin{tabular}{ll}
\hline N & $\mathbf{2 7}$ \\
\hline Cochran's $\boldsymbol{Q}$ & $173.651^{\mathrm{a}}$ \\
\hline df & 21 \\
\hline Asymp.Sig &, 000 \\
\hline
\end{tabular}

Sumber: (Riyanto et al., 2018)

is treated as a success $\rightarrow \chi^{2} 0.05 ;(8)=32.671$

1. Taraf nyata $(\alpha)=5 \%=0,05$

2. Statistik uji yang digunakan : $\chi^{2}$ (khi-kuadrat)

3. Nilai kritis $=$ nilai tabel

$$
\chi_{\text {tabel }}^{2}=\chi^{2} \alpha ;(\mathrm{k}-1)=\chi^{2} 0.05 ;(20)=32.671
$$

4. Kriteria pengambilan keputusan :

$$
\chi^{2} \text { hitung }\left\{\begin{array}{l}
\leq \chi_{\text {tabel }}^{2} \rightarrow \text { terima } \mathrm{H}_{0} \\
>\chi_{\text {tabel }}^{2} \rightarrow \text { tolak } \mathrm{H}_{0}
\end{array}\right.
$$

5. a. Perhitungan :

$$
\chi^{2} \text { hitung }=\frac{(\mathrm{k}-1)\left[\mathrm{k} \Sigma C_{j^{2}}-\Sigma C_{j}\right]}{\mathrm{k} \Sigma R_{i}-\Sigma R_{i^{2}}}=\mathbf{1 7 3 , 6 5 1}
$$

b. Pengambilan keputusan :

$$
\begin{aligned}
& \chi^{2} \text { hitung }<\chi_{\text {tabel }}^{2} \\
& (173,651)>(32.671) \quad \rightarrow \quad \text { Tolak } \mathrm{H}_{0}
\end{aligned}
$$

Berdasarkan hasil perhitungan pada taraf $5 \%$ dapat ditunjukkan bahwa proporsi kesepakatan semua atribut adalah berbeda artinya belum terdapat kesepakatan atau terdapat perbedaan tanggapan responden tentang atribut. Maka harus ada implikasi,

\begin{tabular}{|c|c|c|}
\hline \multicolumn{3}{|c|}{ Frequencies } \\
\hline & \multicolumn{2}{|c|}{ Value } \\
\hline & 0 & 1 \\
\hline KEAMANAN & 6 & 21 \\
\hline PRIVASI & 7 & 20 \\
\hline WAKTU RESPON & 8 & 19 \\
\hline TAMPILAN VISUAL & 5 & 22 \\
\hline TERSEDIA 24JAM & 5 & 22 \\
\hline $\begin{array}{l}\text { PROSES KECEPATAN } \\
\text { HALAMAN }\end{array}$ & 8 & 19 \\
\hline $\begin{array}{l}\text { MEMAHAMI KEMAMPUAN } \\
\text { FLATFORM }\end{array}$ & 8 & 19 \\
\hline DATA UP TO DATE & 6 & 21 \\
\hline KETEPATAN KONTEN & 5 & 22 \\
\hline AKTUALITAS & 3 & 24 \\
\hline $\begin{array}{l}\text { PEMELIHARANAAN } \\
\text { AKUN }\end{array}$ & 7 & 20 \\
\hline STATUS PESANAN & 2 & 25 \\
\hline INFORMASI & 1 & 26 \\
\hline $\begin{array}{l}\text { KEMUDAHAN } \\
\text { TRANSAKSI }\end{array}$ & 3 & 24 \\
\hline NONAKTIF PELAYANAN & 7 & 20 \\
\hline TRANSAKSI & 0 & 27 \\
\hline HEDONIS & 5 & 22 \\
\hline TETERTIMUVSTO & 25 & 4 \\
\hline LAYANAN TANYA JAWAB & 8 & 19 \\
\hline WER SERVER & 24 & 3 \\
\hline TERKENAL & & \\
\hline 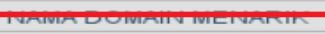 & 24 & \\
\hline $\begin{array}{l}\text { INTEGRASI WEBSITE } \\
\text { LAIN }\end{array}$ & 7 & 20 \\
\hline
\end{tabular}
dengan dilakukan pengujian ulang dengan menghilangkan atribut dengan proposi kesepakatan terkecil. Pengujian ulang kesepakatan atribut dengan Cochran Q Test.

Sumber: (Riyanto et al., 2018)

Gambar 5. Pengujian Ulang Dengan Menghilangkan Atribut Dengan Proposi Kesepakatan Terkecil Tabel 3. Test Statistics Pengujian Ulang

\begin{tabular}{ll}
\hline $\mathbf{N}$ & $\mathbf{2 7}$ \\
\hline Cochran's $\boldsymbol{Q}$ & $25,306^{\mathrm{a}}$ \\
\hline $\mathbf{d f}$ & 18 \\
\hline Asymp.Sig &, 117 \\
\hline
\end{tabular}

Sumber: (Riyanto et al., 2018)

is treated as a success $\rightarrow \chi^{\mathbf{2}} \mathbf{0 . 0 5} ;(\mathbf{8})=\mathbf{2 8 , 8 6 9}$

1. Taraf nyata $(\alpha)=5 \%=0,05$

2. Statistik uji yang digunakan : $\chi^{2}$ (khi-kuadrat)

3. Nilai kritis $=$ nilai tabel

$$
\chi_{\text {tabel }}^{2}=\chi^{2} \alpha ;(\mathrm{k}-1)=\chi^{2} 0.05 ;(20)=32,671
$$

4. Kriteria pengambilan keputusan :

$$
\chi^{2} \text { hitung }\left\{\begin{array}{l}
\leq \chi^{2} \text { tabel } \rightarrow \text { terima } \mathrm{H}_{0} \\
>\chi_{\text {tabel }}^{2} \rightarrow \text { tolak } \mathrm{H}_{0}
\end{array}\right.
$$

5. a. Perhitungan :

$$
\chi_{\text {hitung }}^{2}=\frac{(\mathrm{k}-1)\left[\mathrm{k} \Sigma C_{j^{2}}-\Sigma C_{j}\right]}{\mathrm{k} \Sigma R_{i}-\Sigma R_{i^{2}}}=\mathbf{2 5 , 3 0 6}
$$

b. Pengambilan keputusan :

$$
\chi^{2} \text { hitung }<\chi^{2} \text { tabel }
$$$$
(25,306)>(28,869) \quad \rightarrow \quad \text { Terima } \mathrm{H}_{0}
$$

Berdasarkan hasil perhitungan ulang pada taraf $5 \%$ dapat ditunjukkan bahwa terdapat kesamaan 
proporsi kesepakatan semua atribut, artinya sudah terdapat kesepakatan tanggapan responden tentang atribut. Atribut bisa digunakan sebagai variabel untuk tahap pengujian berikutnya.

Fase membuat hirarki model pada atribut yang telah diuji

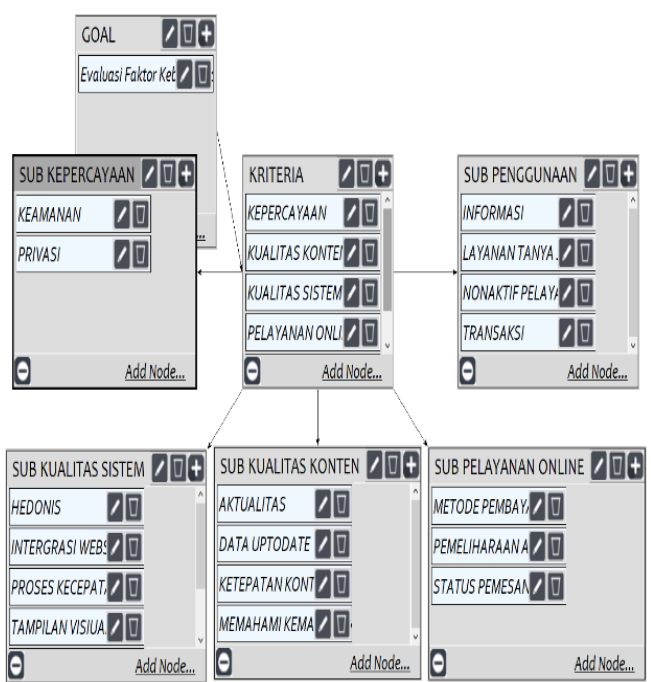

Sumber: (Riyanto et al., 2018)

Gambar 6. Diagram Model Hirarki Dengan Aplikasi Super Decisions 3.2

Langkah selanjutnya yaitu fase kuantifikasi model:

1. Matriks Berpasangan Kriteria Utama

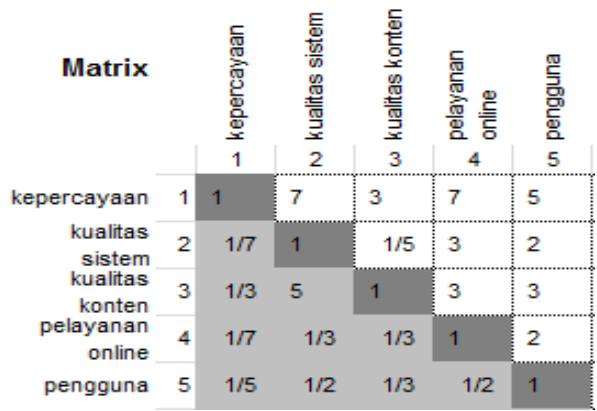

Sumber: (Riyanto et al., 2018)

Gambar 7. Kriteria Utama Aplikasi Gojek

Pada gambar 7 menjelaskan tentang membuat matrix kriteria utama aplikasi gojek sebagai acuan pembobotan berdasarkan olahan dari tanggapan responden.

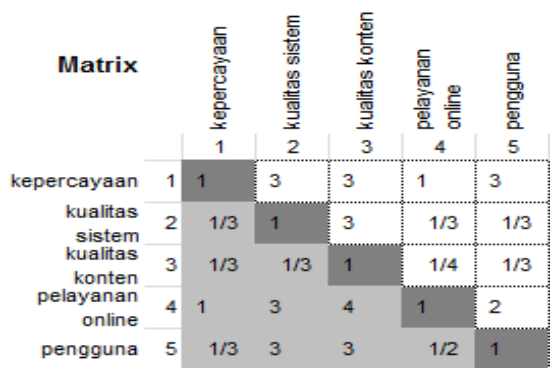

Sumber: (Riyanto et al., 2018)

Gambar 8. Kriteria Utama Aplikasi Grab
Pada gambar 8 menjelaskan tentang membuat matrix kriteria utama aplikasi grab sebagai acuan pembobotan berdasarkan olahan dari tanggapan responden.

2. Matriks Berpasangan Subkriteria Kepercayaan

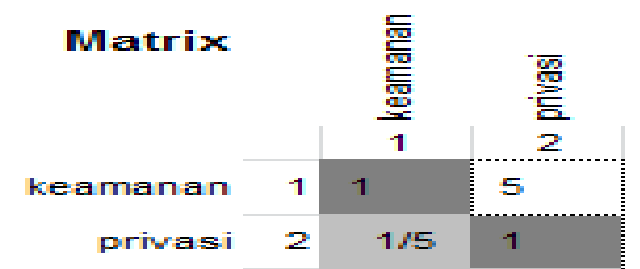

Sumber: (Riyanto et al., 2018)

Gambar 9. Subkriteria Kepercayaan Aplikasi Gojek

Pada gambar 9 menjelaskan tentang membuat matrix subkriteria kepercayaan aplikasi gojek sebagai acuan pembobotan berdasarkan olahan dari tanggapan responden.

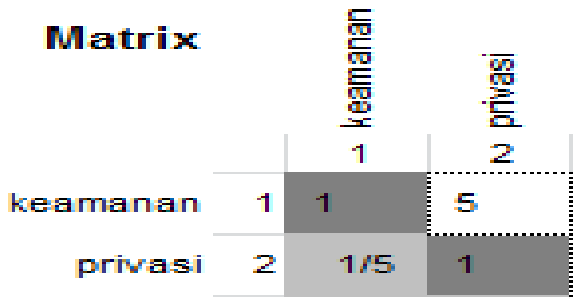

Sumber: (Riyanto et al., 2018)

Gambar 10. Subkriteria Kepercayaan Aplikasi Grab

Pada gambar 9 menjelaskan tentang membuat matrix subkriteria kepercayaan aplikasi gojek sebagai acuan pembobotan berdasarkan olahan dari tanggapan responden.

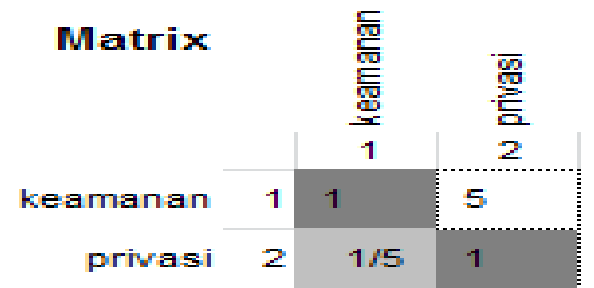

Sumber: (Riyanto et al., 2018)

Gambar 10. Subkriteria Kepercayaan Aplikasi Grab

Pada gambar 10 menjelaskan tentang membuat matrix subkriteria kepercayaan aplikasi grab sebagai acuan pembobotan berdasarkan olahan dari tanggapan responden.

3. Matriks Berpasangan Subkriteria Kualitas Sistem

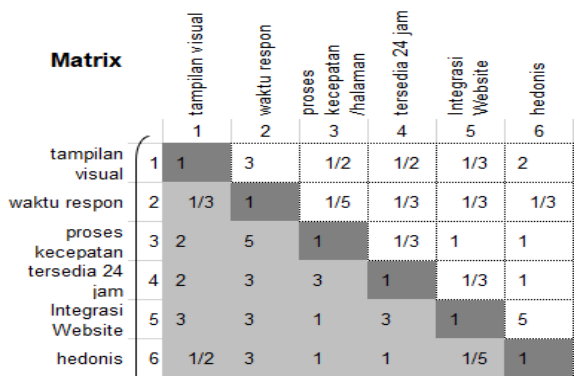


Sumber: (Riyanto et al., 2018)

Gambar 11. Subkriteria Kualitas Sistem Gojek Pada gambar 11 menjelaskan tentang membuat matrix subkriteria kualitas sistem aplikasi gojek sebagai acuan pembobotan berdasarkan olahan dari tanggapan responden.

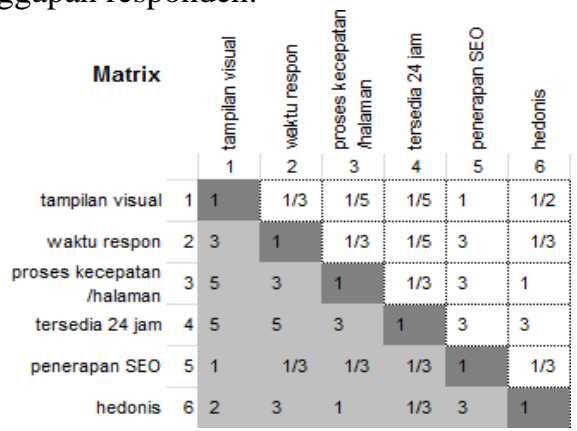

Sumber: (Riyanto et al., 2018)

Gambar 12. Subkriteria Kualitas Sistem Grab

Pada gambar 12 menjelaskan tentang membuat matrix subkriteria kualitas sistem aplikasi grab sebagai acuan pembobotan berdasarkan olahan dari tanggapan responden.

4. Matriks Berpasangan Subkriteria Kualitas Konten

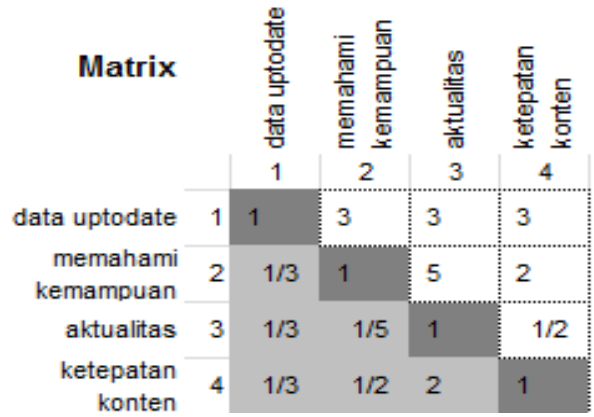

Sumber: (Riyanto et al., 2018)

Gambar 13. Subkriteria Kualitas Konten Gojek

Pada gambar 13 menjelaskan tentang membuat matrix subkriteria kualitas konten aplikasi gojek sebagai acuan pembobotan berdasarkan olahan dari tanggapan responden.

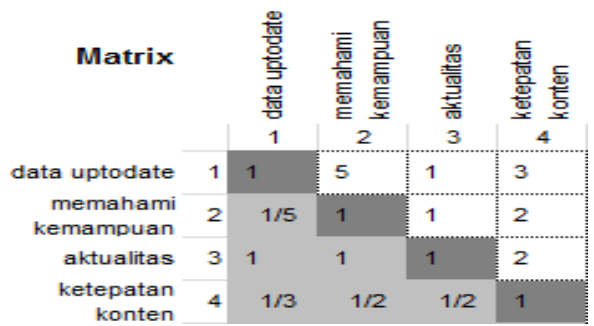

Sumber: (Riyanto et al., 2018)

Gambar 14. Subkriteria Kualitas Konten Grab

Pada gambar 14 menjelaskan tentang membuat matrix subkriteria kualitas konten aplikasi grab sebagai acuan pembobotan berdasarkan olahan dari tanggapan responden.
5. Matriks Berpasangan Subkriteria Pelayanan Online

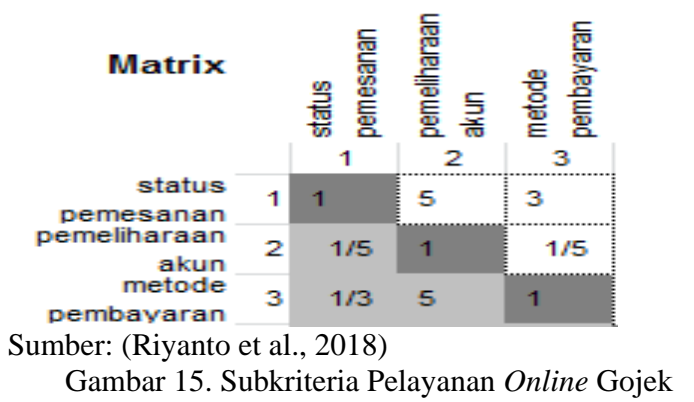

Pada gambar 15 menjelaskan tentang membuat matrix subkriteria pelayanan online aplikasi gojek sebagai acuan pembobotan berdasarkan olahan dari tanggapan responden.

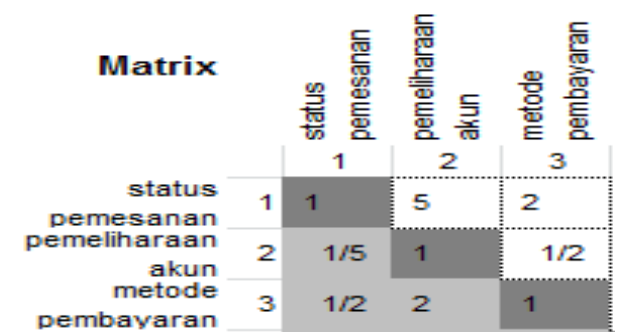

Sumber: (Riyanto et al., 2018)

Gambar 16. Subkriteria Kualitas Pelayanan Online Grab

Pada gambar 16 menjelaskan tentang membuat matrix subkriteria pelayanan online aplikasi grab sebagai acuan pembobotan berdasarkan olahan dari tanggapan responden.

6. Matriks Berpasangan Subkriteria Penggunaan

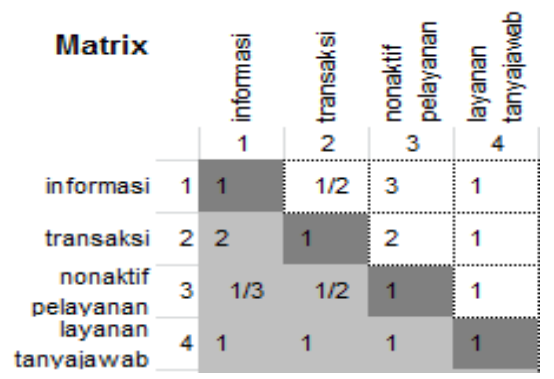

Sumber: (Riyanto et al., 2018)

Gambar 17. Subkriteria Kualitas Penggunaan Gojek

Pada gambar 17 menjelaskan tentang membuat matrix subkriteria penggunaan aplikasi gojek sebagai acuan pembobotan berdasarkan olahan dari tanggapan responden.

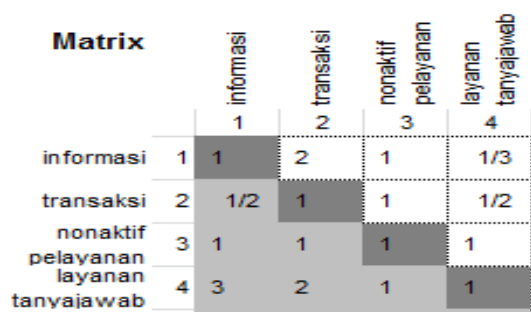


Sumber: (Riyanto et al., 2018)

Gambar 18. Subkriteria Kualitas Penggunaan Grab

Pada gambar 18 menjelaskan tentang membuat matrix subkriteria penggunaan aplikasi grab sebagai acuan pembobotan berdasarkan olahan dari tanggapan responden.

Menghitung nilai rasio konsistensi kriteria atau sub kriteria, jika hasil konsitensi rasio dibawah $10 \%$ atau lebih kecil dari 0.1 maka matrik perbandingan berpasangan tersebut dapat diterima atau mendapat nilai yang konsisten.

1. Bobot dan konsistensi rasio pada Gojek

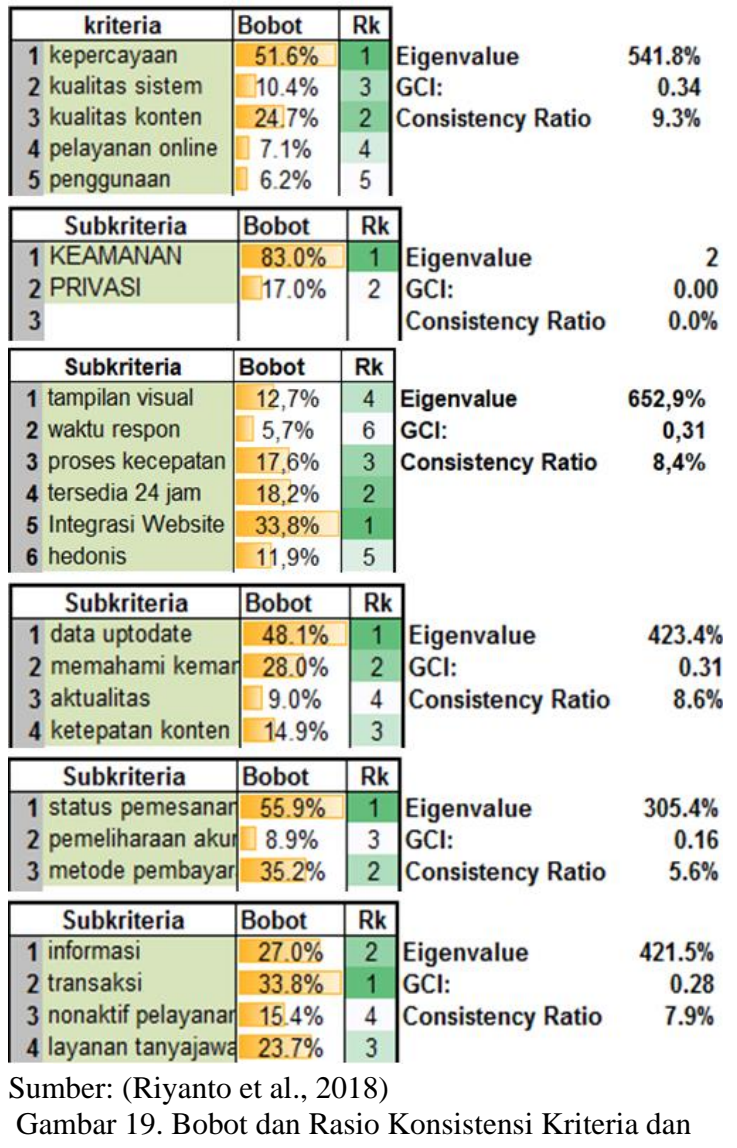

Subkriteria Gojek

Pada gambar 19. Merupakan hasil dari konsistensi Rasio kriteria dan subkriteria dengan hasil dibawah $10 \%$ atau 0.1 dianggap konsisten atau dapat diterima pada aplikasi Gojek.
2. Bobot dan konsistensi rasio pada Grab

\begin{tabular}{|c|c|c|c|c|}
\hline kriteria & Bobot & $\mathrm{Rk}$ & & \\
\hline 1 kepercayaan & $32.9 \%$ & 1 & Eigenvalue & $526.4 \%$ \\
\hline 2 kualitas sistem & $11.1 \%$ & 4 & GCl: & 0.21 \\
\hline 3 kualitas konten & $6.7 \%$ & 5 & Consistency Ratio & $5.9 \%$ \\
\hline 4 pelayanan online & $30.6 \%$ & 2 & & \\
\hline 5 penggunaan & $18.7 \%$ & 31 & & \\
\hline Subkriteria & Bobot & Rk & & \\
\hline 1 keamanan & $83.0 \%$ & 1 & Eigenvalue & 2 \\
\hline 2 privasi & $17.0 \%$ & 2 & $\mathrm{GCl}:$ & 0.00 \\
\hline 3 & & & Consistency Ratio & $0.0 \%$ \\
\hline Subkriteria & Bobot & Rk & & \\
\hline 1 tampilan visual & $5,7 \%$ & 6 & Eigenvalue & $642,1 \%$ \\
\hline 2 waktu respon & $10,5 \%$ & 4 & GCl: & 0,25 \\
\hline 3 proses kecepatan & $20,3 \%$ & 2 & Consistency Ratio & $6,7 \%$ \\
\hline 4 tersedia 24 jam & $39,5 \%$ & 1 & & \\
\hline 5 Integrasi Website & $6,4 \%$ & 5 & & \\
\hline 6 hedonis & $17,6 \%$ & 3 & & \\
\hline Subkriteria & Bobot & $\mathrm{Rk}$ & & \\
\hline 1 data uptodate & $48.1 \%$ & 1 & Eigenvalue & $423.4 \%$ \\
\hline 2 memahami kemar & $28.0 \%$ & 2 & GCl: & 0.31 \\
\hline 3 aktualitas & $9.0 \%$ & 4 & Consistency Ratio & $8.6 \%$ \\
\hline 4 ketepatan konten & $14.9 \%$ & 3 & & \\
\hline Subkriteria & Bobot & Rk & & \\
\hline 1 status pemesanar & $59.5 \%$ & 1 & Eigenvalue & $300.6 \%$ \\
\hline 2 pemeliharaan akur & $12.8 \%$ & 3 & GCl: & 0.02 \\
\hline 3 metode pembayar & $27.6 \%$ & 2 & Consistency Ratio & $0.6 \%$ \\
\hline Subkriteria & Bobot & Rk & & \\
\hline 1 informasi & $21.7 \%$ & 3 & Eigenvalue & $421.5 \%$ \\
\hline 2 transaksi & $16.7 \%$ & 4 & GCI: & 0.28 \\
\hline 3 nonaktif pelayanar & $23.7 \%$ & 2 & Consistency Ratio & $7.9 \%$ \\
\hline 4 layanan tanyajawa & $38.0 \%$ & 1 & & \\
\hline \multicolumn{5}{|c|}{ Sumber: (Riyanto et al., 2018) } \\
\hline
\end{tabular}

Pada gambar 20. Merupakan hasil Hasil dari konsistensi Rasio kriteria dan subkriteria dengan hasil dibawah $10 \%$ atau 0.1 dianggap konsisten atau dapat diterima pada aplikasi Grab.

\section{KESIMPULAN}

Hasil penelitian ini menunjukan dalam membangun suatu usaha transportasi berbasis mobile, ada halnya pemilik harus menerapkan lima kriteria utama dalam membangun aplikasi pada sisi teknologi, yaitu kepercayaan, kualitas sistem dan konten, pelayaan online dan cara penggunaan. Berdasarkan isu maupun hipotesis, terbukti bahwa faktor utama yang sangat berpengaruh dengan keberhasilan suatu aplikasi bisa dilihat dari tingkat kepercayaan teknologi dari aplikasi transportasi. Faktor penunjang dalam membangun bisnis berbasis aplikasi online pun tidak hanya faktor kepercayaan saja, adanya sub kriteria-kriteria yang wajib diterapkan untuk memastikan asplikasi tersebut bisa berhasil digunakan dan fungsional yaitu adanya faktor keamanan dan status pemesanan. Dimana hal 
ini yang membuat pengunjung nyaman akan penggunaan aplikasi tersebut dan bisa mengetahui proses pada status layanan atupun pemesanan produk yang dapat digunakan pengunjung sebagai alat monitoring layanan atau pemesanan.

\section{REFERENSI}

Abdul, S., Nasution, U. C., \& Awin, M. (2017). Pengaruh Kualitas Pelayanan dan Promosi Terhadap Keputusan Konsumen Membeli Tiket Pesawat Online di Traveloka. Dinamika Administrasi Bisnis, 3(1). Retrieved from http://jurnal.untagsby.ac.id/index.php/adbis/article/view/2348

Ekawati, \& Niken, N. (2014). Kajian Dampak Pengembangan Pembangunan Kota Malang Terhadap Kemacetan Lalu Lintas (Studi pada Dinas Perhubungan Kota Malang). Jurnal Administrasi Publik, 2(1), 129-133. Retrieved from

http://administrasipublik.studentjournal.ub.ac.i d/index.php/jap/article/view/352

Minesa, P., Siregar, H., \& Manuwoto. (2014). Aplikasi Analytical Hierarchy Process (AHP) Dalam Penentuan Skala Prioritas Penyelenggaraan Jalan Di Kecamatan Cibinong Kabupaten Bogor. Jurnal Manajemen Pembangunan Daerah, 6. Retrieved from http://journal.ipb.ac.id/index.php/jurnalmpd/ar ticle/view/25099/16304

Nadhiroh, U. (2019). Pengaruh Motivasi Dan Kepuasan Kerja Terhadap Kinerja Karyawan Dengan Budaya Organisasi Sebagai Variabel Moderating Pada Koperta Langgeng Mulyo Ngancar Kediri. Develop, 3(1), 61-77. Retrieved from https://ejournal.unitomo.ac.id/index.php/ep/art icle/view/1531

Ngafifi, M. (2014). Kemajuan Teknologi Dan Pola Hidup Manusia Dalam Perspektif Sosial Budaya. Jurnal Pembangunan Pendidikan: Fondasi Dan Aplikasi, 2(1). https://doi.org/10.21831/JPPFA.V2I1.2616

Rahma, N., Soeaidy, M. S., \& Hadi, M. (2013). Peranan Dinas Perhubungan dalam Meningkatkan Pelayanan Masyarakat di Bidang Angkutan Kota (Studi pada Dinas
Perhubungan Kota Malang). Jurnal

Administrasi Publik, 1(7), 1296-1304.

Retrieved from

http://administrasipublik.studentjournal.ub.ac.i d/index.php/jap/article/view/204

Riyanto, V., Rosyida, S., \& Ridwansyah. (2018). Evaluasi Faktor Keberhasilan Sistem Informasi Transportasi Online Berbasis Mobile Dalam Perspektif Kepuasan Pelanggan. Laporan Penelitian Dosen Pemula. Tresiya, D., Djunaidi, D., \& Subagyo, H. (2018). Pengaruh Kualitas Pelayanan Dan Kenyamanaan Terhadap Kepuasan Konsumen Pada Perusahaan Jasa Ojek Online Go-Jek Di Kota Kediri. Jimek, 1(2), 208-224. Retrieved from http://ojs.unikkediri.ac.id/index.php/jimek/article/view/310

Zaini, D. Z. (2012). Perspektif Hukum Sebagai Landasan Pembangunan Ekonomi Di Indonesia (Sebuah Pendekatan Filsafat). Jurnal Hukum, XXVIII, 929-957. Retrieved from

http://jurnal.unissula.ac.id/index.php/jurnalhuk um/article/view/220

\section{PROFIL PENULIS}

Verry Riyanto, mendapatkan gelar Sarjana Komputer diperoleh dari Program Studi Sistem Informasi pada tahun 2010 di STMIK Nusa Mandiri Jakarta, Gelar Magister Ilmu Komputer diperoleh dari Program Studi Ilmu Komputer pada tahun 2014 di Pascasarjana STMIK Nusa Mandiri Jakarta. Sekarang ini mengajar sebagai Dosen pada Sekolah Tinggi STMIK Nusa Mandiri Jakarta.

Susy Rosyida, M.Kom. Tahun 2010 lulus dari Program Strata Satu (S1) Program Studi Sistem Informasi STMIK Nusa Mandiri Jakarta. Tahun 2013 lulus dari Program Strata Dua (S2) Program Studi Magister Ilmu Komputer STMIK Nusa Mandiri Jakarta. Saat ini bekerja sebagai tenaga pengajar di STMIK Nusa Mandiri Jakarta.

Ridwansyah sebagai tenaga pengajar pada STMIK Nusa Mandiri Jakarta Prodi Teknik Informatika. Memperoleh gelar Sarjana Komputer pada tahun 2011 di STMIK Nusa Mandiri Jakarta, prodi Sistem Informasi. Memperoleh gelar Magister Komputer pada STMIK Nusa Mandiri Jakarta tahun 2014. 